Studia Slavica Savariensia 2016. 1-2. 252-257

DOI: $10.17668 /$ SSS.2016.1-2.252

\author{
Kanizsai Mária \\ (Baja, Magyarország)
}

\title{
A ZALAI KAJ-HORVÁT RAGADVÁNYNEVEK
}

(Kutatási téma ismertetése)

\begin{abstract}
In my present essay I would like to outline some ideas regarding the folk nicknames of the Kajkavian ethnic group in Zala county. I will shortly present the field of research, the characteristics of their use of language, the research material and I will touch upon some of the characteristics of family nicknames.
\end{abstract}

Keywords: Kajkavian ethnic group of Zala county, bilingualism, family and individual nicknames

\section{Kutatási terület - népcsoport}

Zala megyében, Nagykanizsa és Letenye között elhelyezkedő öt községben: Tótszentmárton, Tótszerdahely, Molnári, Semjénháza, Petrivente, Fityeház saját nevükön: Sumarton, Serdahel, Mlinarce, Pustara, Petriba, Fićehaz községekben - horvátajkú, a magyarországi horvát nemzetiségủ népcsoporthoz tartozó lakosság él. A területi elhelyezkedés folytán Mura menti horvátoknak nevezzük őket. Anyanyelvük a horvát nyelv kaj nyelvjárástípusába tartozik, annak megyimurjei (muraközi) változatát beszélik, amely a történelem során az anyaországtól való területi és nyelvi elszigeteltség következtében számos regionális és archaikus jegyet mutat, egyedülálló nyelvjárásszigetet képez.

Đuro Blažeka a nyelvterületen, Tótszerdahelyen végzett dialektológiai kutatásait tartalmazó, átfogó jellegủ munkájában, a 2008-ban megjelent Međimurski dijalekt címü könyvében fonológiai és morfológiai jegyek alapján a megyimurjei (muraközi) nyelvjárást további három alcsoportra osztja: felső, középső és alsó muraközi aldialektust különböztet meg. A Mura menti horvátok által beszélt lokális nyelvjárást „,serdaheljska skupina” szerdahelyi csoport néven az alsó muraközi csoportba sorolja Prelog, Goričan, Donja Dubrava és Orehovica községek nyelvjárásával együtt (BLAŽEKA 2008: 14). Zala megyén kívül Magyarország két másik területén beszélik még a kaj-horvát nyelvjárás regionális változatát: Vas megyében Fertőhomok (Umok) és Hidegség (Vedešin) községekben, valamint a Dráva mentén Babócsa és Lakócsa (Lukovisče) községekben és környékükön. 


\section{Nyelvhasználat}

A zalai horvátok nyelvhasználata az egykori egynyelvüségtől halad a kétnyelvüségen át a nyelvvesztés felé. Horvát egynyelvü anyanyelvi beszélő ma már nem található a községekben, néhány nagyon idős lakosnál még előfordulhat az anyanyelv-domináns kétnyelvüség, de általánosan jellemző a másodnyelv-domináns kétnyelvüség, a fiatalok között sokak számára pedig már iskolában tanult nyelvvé válik. A községekben élö értelmiségi réteg körében a diglosszia, triglosszia is jellemzö. Igen változatos nyelvhasználat figyelhető meg, személyhez, életkorhoz, generációhoz, beszédszíntérhez, témához, a beszélő státuszához és a kommunikációs funkcióhoz kötődően használatos a zalai kaj-horvát helyi nyelvjárás, a horvát köznyelv és a magyar nyelv. A zalai horvátok lokális nyelvjárásában fonológia különbségek figyelhetők meg az egyes községek lakóinak beszéde között, az a fonéma nyíltabb vagy zártabb ejtésében.

A népcsoportot a területi elhelyezkedésen túl ma is összetartja a közös történelmi múlt és eredet tudata, a közös nyelvi, kulturális jellemzők és hagyományok, az egykori nagycsaládi életmódból következő, házassági szokásokból megmaradt rokoni kötődések. A népcsoport életében erős asszimilációs jegyek figyelhetők meg, a községek lakossága elöregedett, jellemző a megélhetési elvándorlás. Kutatásom kizárólag a felsorolt községek lakosságának névanyagára vonatkozik, a Letenye, Nagykanizsa, Pécs, Budapest és más közeli és távolabbi helységekben élö, elszármazott személyekre nincs adat, nem vehetők figyelembe.

Az említett nyelvi és nyelven kívüli tényezők meghatározzák a népcsoport névtani, névhasználati sajátosságait, a dialektológiai jellemzők, a kétnyelvüség nyelvi, nyelvhasználati jelenségei a ragadványnevekben is erősen tükröződnek.

\section{Kutatási anyag}

A zalai horvát ragadványnevek kutatásához a területen gyüjtött kb. 1000 nevet tartalmazó adatbázis áll rendelkezésemre. A nevek gyüjtését Tótszentmárton, Tótszerdahely, Molnári, Semjénháza, Petrivente, Fityeház községekben 2000-ben végezte Nikli Hajnalka egyetemi hallgató. Az egyes községekben 3-4 idős, a helyi kaj-horvát nyelvjárást jól beszélő adatközlőtől irányított beszélgetés keretében, a hivatalos lakónyilvántartás alapján az egyes családokban használatos családi és egyéni ragadványneveket írta össze abban a fonetikai alakban, ahogy a neveket használják. Így 825 névadatot tartalmazó adatbázis állított össze. Az gyüjtés során kérdezte a névadás indítékát is, amire a régóta használatos nevek esetében nehéz megbízható adatot találni. A névanyagot további névtani feldolgozás és kutatás céljára a rendelkezésemre bocsájtotta. A vizsgálati anyagot édesanyám, Proszenyák Anna (szül. 1943.) Tótszerdahelyre vonatkozó további 200 adatával egészítettem ki. Az adatok a 2000 és 2012. évi szinkrón állapotot tükrözik, de következtetni engednek a névanyag változására is. A folyamatos adatközlés következtében a bázis frissül, 
így módom van a régi, kivesző ragadványnevek mellett követni az új nevek keletkezését, az állomány dinamikus változását. Célom a névanyag rögzítése, rendszerezése és tudományos igényü vizsgálata.

\section{A ragadványnevekről}

A ragadványnevek meghatározásában a magyar és horvát szakirodalomban is egyetértenek abban, hogy a személynevek között a nem hivatalos nevek közé tartoznak, a szóbeli, többnyire informális kommunikációban használatosak, keletkezésük és müködésük közege a közösség, abban általánosan ismertek, említő és megszólító, vagy csúfnévként használatosak, gyakran generációkon át öröklődnek, feladatuk a pontosabb azonosítás.

„...ragadványnévnek nevezem mindazokat a nem anyakönyvezett vagy névszerü szókat, a) amelyek a hivatalos iratokon mint megkülönböztető szerepü nevek szerepelnek; b) amelyek a szóbeli névrendszerben müködnek, akár mint közömbös hangulatú ragadványnevek, akár mint expresszív hangulatú, elismerést, kedveskedést kifejező bóknevek, illetőleg csúfolódó hangulatú gúnynevek" (ÖRDÖG 1973: 154).

„Azokat a névelemeket, amelyeket a hivatalos kereszt és családneveken, valamint beceneveken kívül az emberek adnak egymásnak bármilyen szándékkal, ragadványneveknek nevezzük. Ezeknek keletkezéséhez mindig valamilyen közösség kell, amelyben személyesen ismerik egymást az elnevezettek és elnevezők" (HAJDÚ 1994: 43).

J. Soltész Katalin és A. Frančić szerint a ragadványneveknek megkülönböztető funkciója van, lehetnek családi és egyéni ragadványnevek, családnevet vagy teljes egyéni nevet pótló, helyettesítő nevek (SOLTÉSZ 1979: 55-65; FRANČIĆ 1993, 1994).

A horvát névtanban megkülönböztetik a valódi családi ragadványnevet, ennek fonológiai alakja eltér a családnévtől (pl.: a Proszenyák családnévhez tartozó egyik valódi családi ragadványnév a Južetove(i), míg a nem valódi családi ragadványnevet a családnévből képezik, pl. Kósa-Košijove(i). (A neveket az ejtés szerinti írásmódban adom meg, -jovi végződésben az $i$ helyett $e$-t ejtenek.)

\section{Zalai horvátok ragadványnév használatának néhány jellemzője}

A személynév funkciója az egyértelmü azonosítás. A zalai horvátok zárt közösségben, nagycsaládi formában éltek, az egymás közötti házasságok révén az azonos családnevek gyakorisága magas még ma is. A népcsoport személyneveinek vizsgálatára vonatkozó korábbi kutatásom eredményei alapján megállapítható, hogy a személynevek (utónevek/keresztnevek) gyakorisága és terheltsége az 1794-től az 1950-60 évekig szintén igen magas volt, így a személynevek nem tudják betölteni elsődleges azonosító, megkülönböztető szerepüket (KANIZSAI 2011: 270-274). Mindezen körülmények kedveztek a gazdag ragadványnévrendszer kialakulásának. 
A zalai horvátok a ragadványneveket cona szóval jelölik a (német Zuname) szóból. A csúfnévre a zmišlanje szót használják. A ragadványnevek lehetnek családi, több generációra visszamenő nagycsaládi ragadványnevek, amelyeket többes számban -ovi, -ini (ejtésben -ove,- ine) képzővel szerepelnek. Ha a családi a ragadványnév egy személyre vonatkozik a hímnemben az -ov, -jov, ev, -jev, -in, nőnemben az -ova, -jova, -eva, -jeva, -ina végződést kapják, valamint társul hozzá a személy keresztneve, gyakran becézett alakban. Az egyéni ragadványnevek nagyon változatosak, sajátos szerkezetủek, egy vagy kételemüek.

Az nevek információs tartalmát, szerepét egy zárt közösség esetében, a személyek azonosításra vonatkozó kérdéseket a saját példámon szemléltetem, hiszen gyermekkoromban magam is számtalanszor megtapasztaltam, a falu idősebb lakosai milyen kérdéseket tették fel, ha nem ismertek meg valakit. Ezzel bepillanthatunk a népcsoport sajátos világába, gondolkodásmódjába is. A kétnyelvüség és kódváltás, kódkeverés következtében a neveket magyar és horvát alakban és ejtésben is használják, a névelemek sorrendje változó is lehet. A személynevek, horvát becézett és magyar alakját is megadom, a horvát alakokat ejtés szerinti írásmódban (a szóvégi $i$ hangot nyíltabban $e$ hangként, az $u$-t $o$-nak ejtik).

- Kaj ti je ime?/Mi a neved? kérdéssel mindig személynévre kérdeznek. Válasz: Ja sem Marica.

- Kak se zoveš?/Kak te zovejo? Hogy hivnak? érthető személynévre és ragadványnévre vonatkozó kérdésként is, általában a személynévvel válaszolnak, ami lehet teljes hivatalos névformula is.

Lehetséges válaszok:

- Ja se zovem Marija - csak személynévvel. A Marija névalak beszédben nem használatos, a becézett alak a gyakori: Ja se zovem Marica. A Mária/Marica személynév az 1950-60-as évekig az egyik leggyakoribb női név a zalai horvát községekben. 1794-1998 közötti egyházi névanyagban 2500 elnevezett személy 25\%-a (628 fö) viselte a Mária nevet (KANIZSAI 2011: 270-274). A név gyakori előfordulása okán ennek a válasznak nincs identifikáló tartalma.

Több információt tartalmaz a teljes kételemü név: -Ja sem Marija Kanižaj.

- Ja sem Marica Kanižajova - nem valódi családi ragadványnévvel, becézett személynévvel. Ez sem volt elégséges információ az egyértelmű azonosításhoz, mivel több ilyen nevü család is élt a faluban, hasonló korú leánygyermekkel.

További kérdést tettek fel:

- Kak ti/vam govore/govorijo? Hogy mondják neked/nektek? vagy Čija si/čiji ste? (Kinek a (fia/lánya) vagy (kihez tartozol/tartozik?)

Ebben az esetben a családhoz való tartozásra, a családi vagy az egyéni ragadványnévre kíváncsiak, a személynévvel és családi ragadványnévvel lehet egyértelmüen azonosító válasz adni.

- Ja sem Marica Repekova. 
Ezen válasz után megértették a családhoz való tartozást, de a teljes azonosítás céljából rendszerint visszakérdezve felsorolták az egész családfámat, sokszor a dédszülőkig visszamenőleg, kizárólag családi ragadványnevekkel és személynevekkel, származási hely, rokonsági fokok megjelölésével:

- Aha, ti si či Štefeka Repekovoga,/Repeka, a mama ti je Janica Južetova, stari japa so ti Marten Repekof koj si je zel za ženo Ronico od Mikulinove, ka ima mamo Evico od Lackove, ka je dosla za sneho s Sumartona.

- Aha, te Stefek Repekof,/Repek lánya vagy, édesanyád pedig Janica Juzsetova, nagyapád Marten Repekof, aki elvette feleségül Ronicát a Mikulinovéktól, kinek az anyja Evica, aki Szentmártonból a Lackovéktól jött menyecskének. (Ha elég idős személy érdeklődött, akkor még egy tréfás történetet is elmesélt a dédszülők megismerkedéséröl.)

- Kak ti/vam zmišlajo? Hogy csúfolnak? kérdéssel többnyire csúfnévre vagy egyéni ragadványnévre kérdeztek, ami nem mindenkinek volt, de családi ragadványnévvel is lehet válaszolni. Ez a kérdés a arra utal, hogy a ragadványnévadás indítéka sokszor csúfolódás lehetett.

$\mathrm{Az}$ említett hosszú válasz a névtani és dialektológiai információkon túl árulkodik a néplélek, a gondolkodásmódról is. A szóbeli, hétköznapi kommunikációban, a közösségen belül a személyek azonosítása és megkülönböztetése a gyakran generációkra visszamenően öröklődő családi ragadványnevek, vagy egyéni ragadványnevek segítségével történt.

Hogy a ragadványnevek a közösségben milyen fontos szerepet töltenek be még napjainkban is, mennyire hozzátartoznak viselőikhez, mutatja egy nemrég felállított márvány síremlék felirata a tótszerdahelyi temetőben: Tu počiva jedna obitelj (čelada): Ferkiceve. Kajhorvát nyelven, írásban, családi ragadványnévvel, a hivatalos nyelvi forma nélkül, a közösséghez tartozás abszolút kifejezése. Egy olyan család sírján, melynek tagjai még beleszülettek a horvát nyelvet beszélő hagyományos paraszti közösségbe, nagycsaládba, személyes sorsukként élték meg annak felbomlását, a népcsoportot érintő társadalmi, gazdasági, nyelvi változásokat. Az utolsó szó jogán így tudatták az utókorral identitásukat, a népcsoporttal, ősökkel való azonosulásukat, érzelmi kötödésüket.

A teljes gyüjtött névanyag tudományos igényű vizsgálata, rendszerezése, értékelése, összehasonlítása a szomszédos horvátországi nyelvterületen végzett névtani kutatások eredményeivel olyan információk feltárására és megőrzésére ad lehetőséget, amelyek a népcsoport kultúrájának, történetének része, megőrzése érték, s számot tarthat a hazai és horvát kutatók érdeklődésére is. 


\section{Irodalom}

BLAŽEKA 2008 = BLAŽEKA Đ. Međimurski dijalekt. Čakovec, 2008.

FRANČIĆ 1994 = FRANČIĆ A. Međimurski obiteljski nadimci. Rasprave ZHJ 20. Zagreb, 1994. 31-66.

FRANČIĆ 1993 = FRANČIĆ A. Međimurski obiteljski nadimci od osobnih imena Rasprave ZHJ 19. Zagreb, 1993.

HAJDÚ 1994 = HAJDÚ M: Magyar tulajdonnevek. Budapest, 1994.

J.SOLTÉSZ 1979 = J. SOLTÉSZ K. A tulajdonnév funkciója és jelentése. Budapest, 1979.

KANIZSAI $2011=$ KANIZSAI M. Személynévvizsgálatok a zalai kaj-horvátok körében 1794-től 1998-ig. Névtani Értesítő 33. sz. Budapest, 2011. 270-274.

ÖRDÖG 1973 = ÖRDÖG F. Személynévvizsgálatok Göcsej és Hetés területén, Budapest, 1973. 